|Araştırma Makalesi / Research Article |

\title{
Ortaokul Öğrencilerinin Yansıtıcı Düşünme Becerileri ile Matematik Öz Yeterlik Algılarının Çeşitli Değişkenler Açısından İncelenmesi
}

\section{Analyzing the Reflective Thinking Skills and Mathematical Self-efficacy Perceptions of Middle School Students with Respect to Some Variables}

\section{Sevim Sevgi ${ }^{1}$, Merve Zihar $^{2}$}

\author{
Anahtar Kelimeler \\ Yansıtıcı düşünme \\ becerisi \\ Öz yeterlik algısı \\ Ortaokul öğrencileri

\section{Keywords \\ Reflective thinking skill \\ Self-efficacy perception} \\ Middle school students
}

Başvuru Tarihi/Received

07.03.2020

Kabul Tarihi /Accepted

02.06.2020

\begin{abstract}
Öz
Bu çalışmanın amacı, ortaokul öğrencilerinin problem çözmeye yönelik yansıtıcı düşünme becerilerini ve matematik öz yeterlik algılarını belirlemek, cinsiyet, sınıf seviyesi ve karne notu değişkenleri açısından incelemektir. Araştırmanın örneklemini 20192020 eğitim öğretim yılı, Kayseri ili Kocasinan ilçesinde bulunan sosyo-ekonomik ve sosyo-kültürel şartlar bakımından orta düzey bir devlet okulunun 5, 6, 7 ve 8 . sınıfında öğrenim gören toplam 421 öğrenci oluşturmaktadır. Tarama yönteminin kullanıldığı araştırmada veriler problem çözmeye yönelik yansıtıcı düşünme becerisi ve matematik öz yeterlik algısı ölçeği kullanılarak bir araya getirilmiş ve Mann Whitney $U$, Kruskal Wallis ve Spearman Korelasyonu ile analiz edilerek değerlendirilmiştir. Elde edilen bulgulara göre ortaokul öğrencilerinin problem çözmeye yönelik yansıtıcı düşünme becerisi ile matematik öz yeterlik algısı ölçeğinden aldıkları toplam puanlar arasında orta düzeyde, pozitif ve anlamlı bir ilişki olduğu görülmüştür. Ayrıca cinsiyete göre yansıtıcı düşünme beceri puanları ile öz yeterlik algısı puanları arasında istatistiksel olarak anlamlı farklılık bulunmazken sınıf düzeyi ve karne notuna göre alt gruplarda istatistiksel olarak anlamlı farklılık bulunmuştur. Beşinci sınıf ortaokul öğrencilerinin yansıtıcı düşünme becerileri sekizinci sınıf ortaokul öğrencilerinin yansıtıcı düşünme becerilerinden, beşinci sınıf ortaokul öğrencilerinin öz yeterlik algıları yedinci sınıf ortaokul öğrencilerinin öz yeterlik algılarından istatistiksel olarak yüksek bulunmuştur. Karne notu 5 olan öğrencilerin ise yansıtıcı düşünme becerileri ile öz yeterlik algılarının karne notu 1-2 olanlar, 3 olanlardan ve 4 olanlardan istatistiksel olarak anlamlı düzeyde yüksek olduğu belirlenmiştir.

\section{Abstract}

This study aims to determine the reflective thinking skills and mathematics self-efficacy perceptions of middle school students in terms of problem-solving in terms of gender, grade level, and mathematics exam scores. The sample was $4215^{\text {th }}, 6^{\text {th }}, 7^{\text {th }}$, and ${ }^{\text {th }}$ graders of a middle school in terms of medium level socio-economic and socio-cultural conditions in Kocasinan, Kayseri in 2019-2020. The survey method was used. The reflective thinking scale and mathematics self-efficacy perception scale for problem-solving were administered and analyzed with the Mann Whitney U, Kruskal Wallis, and Spearman Correlation. According to the findings, there was a moderate, positive, and significant relationship between reflective thinking skills and mathematics self-efficacy perception for problem-solving scale. Also, there was no significant mean difference between girls and boys in reflective thinking skill and mathematics self-efficacy perception for problem-solving. Still, a significant mean difference was found across grade levels and mathematics scores. The reflective thinking skills of $5^{\text {th }}$ grade students were higher than the reflective thinking skills of $8^{\text {th }}$ grade students. The self-efficacy perceptions of the $5^{\text {th }}$ grade were higher than the selfefficacy perceptions of the $7^{\text {th }}$ grade. Reflective thinking skills and self-efficacy perceptions of students with a mathematic score of 5 were significantly higher than those with a mathematic score of $1-2,3$, and 4.
\end{abstract}

\section{Extended Abstract}

\section{Introduction}

This study aimed to investigate whether reflective thinking skills and mathematics self-efficacy perceptions of middle school students change according to some variables and evaluate their reflective thinking skills and mathematics self-efficacy perception levels. It was also aimed to examine whether there was a significant relationship between reflective thinking skills and mathematics self-efficacy perceptions. The research problem of this study was: "Are reflective thinking skills and mathematics self-efficacy perceptions of middle school students affected by some variables?" Sub-research problems of this research:

- What is the level of reflective thinking skills and self-efficacy perceptions of middle school students towards problemsolving?

- Is there a statistically significant mean difference in reflective thinking skills and self-efficacy perceptions towards problem-solving according to gender?

- Is there a meaningful relationship between reflective thinking skills and mathematics self-efficacy perceptions of middle school students towards problem-solving?

\footnotetext{
${ }^{1}$ Sorumlu Yazar, Erciyes Üniversitesi, Eğitim Fakültesi, Matematik ve Fen Bilimleri Eğitimi Bölümü, Kayseri, TÜRKiYE; https://orcid.org/0000-0002-6611-5543 ${ }^{2}$ Erciyes Üniversitesi, Eğitim Bilimleri Enstitüsü, Matematik Eğitimi ABD, Kayseri, TÜRKiYE; https://orcid.org/0000-0002-8960-8885
}

Alıntı/Citation: Sevgi, S., Zihar, M. (2020). Ortaokul öğrencilerinin yansıtıcı düşünme becerileri ile matematik öz yeterlik algılarının çeşitli değişkenler açısından incelenmesi. Kastamonu Education Journal, 28(6), 2331-2345. doi: 10.24106/kefdergi.700428 
- Are there statistically significant mean differences in reflective thinking skills and self-efficacy perceptions for problem-solving according to grade levels?

- Is there any statistically significant mean difference in reflective thinking skills and self-efficacy perceptions for problem-solving according to mathematics exam scores?

\section{Method}

The research was a descriptive and general survey model. This method was a research approach in which a problem encountered in the past or present is visible. The study sample consisted of students in the $5^{\text {th }}, 6^{\text {th }}, 7^{\text {th }}$, and $8^{\text {th }}$ grade of a middle school in terms of socio-economic and socio-cultural conditions in Kocasinan, Kayseri district, 2019-2020 academic year.

\section{Result and Discussion}

The mean of middle school students' reflective thinking skill scores was 51.84 and the mean of self-efficacy scores was 50.04 . According to these values, middle school students' reflective thinking skills and self-efficacy perceptions had a higher value than average.

When the Mann Whitney U test results were analyzed, there was no statistically significant mean difference between students' reflective thinking skills according to gender [Mann Whitney $U=20651 ; z=-1.145 ; p=0.252$ ]. As in reflective thinking skills, students' perceptions of self-efficacy did not show statistically significant mean difference according to gender [Mann Whitney $U$ $=22002 ; z=-0.060 ; p=0.952$ ]. According to this result, it was possible to say that there was no statistically significant mean difference in the reflective thinking skills and perceptions of mathematics self-efficacy of female and male students.

It can be concluded that students' reflective thinking skills differ statistically significantly according to grade levels $\left[X^{2}(3, n=\right.$ $421)=8.726 ; p=0.033]$. Since the significance value calculated for self-efficacy was $p=0.027<0.05$, students' perceptions of selfefficacy also showed a significant mean difference according to grade level $\left[X^{2}(3, n=421)=9.155 ; p=0.027\right]$. The Mann Whitney $\mathrm{U}$ test, which compared two independent samples from nonparametric tests, was used to determine the subgroups' differences. There was a statistically significant mean difference between the fifth and eighth-grade groups' reflective thinking skills in favor of the fifth grade. There was a statistically significant difference between the self-efficacy perceptions of fifth to seventh-grade levels in favor of the fifth grade.

It can be concluded that students' reflective thinking skills statistically differ significantly according to the mathematics scores $\left[X^{2}(3, n=421)=26.092 ; p=0.000\right]$. Students' perceptions of self-efficacy also differ statistically significantly according to the mathematics scores $\left[X^{2}(3, n=421)=37.559 ; p=0.000\right]$. There was a statistically significant mean difference between the mathematics scores' reflective thinking skills (1-2) -5, 3-5, and 4-5 in the mathematics scores groups in favor of those who receive grade point 5 . In addition to the reflective thinking skills of the grades of (1-2) - 5, 3-5, and 4 - 5, there was a significant mean difference between the perceptions of self-efficacy in favor of those who receive mathematics scores of 5.

This study reflects the reflective thinking skills and perceptions of mathematics self-efficacy towards middle school students' problem-solving. The findings obtained from the data analysis are discussed and compared with the research in the literature. According to the study's findings, if we examine the reflective thinking skills and self-efficacy perception levels of middle school students, middle school students' reflective thinking skills and mathematics self-efficacy perception scores were higher based on their scores. Erdoğan (2019) examined middle school students' reflective thinking skills in terms of some variables, the general level of reflective thinking skills of students was low. When the results obtained were compared with the studies, these values were lower than the scores obtained from studies with science and art centers and gifted children (Güneş, 2015; Kaplan, Doruk \& Öztürk, 2014; Saygılı \& Atahan, 2014). This is because these students were selected and accepted in the schools by exam. Also, higher averages were observed in the studies conducted in primary schools (Bilgiç, 2017). Higher scores indicate that reflective thinking can be used more actively in primary and middle school curricula.

Ipek (2019) found that mathematics self-efficacy perceptions of middle school students were found to be moderate. Akay and Boz (2011) analyzed pre-service teachers' attitudes towards mathematics, self-efficacy perceptions against mathematics, and teacher self-efficacy beliefs. The attitudes, mathematics competence perceptions, and academic achievement of the sample students were sufficiently high. According to Bandura (1997), a person's confidence in his or her talents and skills is a prerequisite for overcoming difficulties. Individuals with high self-efficacy are more determined, more diligent, more persistent, and more positive in difficult and challenging learning tasks (Zimmerman, 2000). Therefore, it provides information about students' mathematics self-efficacy, their capacity to learn a subject successfully, and their beliefs.

When the findings were evaluated based on gender, there was no statistically significant mean difference between the reflective thinking skills of problem-solving and mathematics self-efficacy perceptions of middle school students in terms of gender. Sayglı and Atahan (2014) stated that gifted children's reflective thinking skills did not change according to gender. Similarly, Durdukoca and Demir (2012) reported no statistically significant relationship between reflective thinking disposition and gender. On the other hand, some studies in the literature find results against the research findings. Tat (2015) concluded that female students' reflective thinking skills towards problem-solving were higher than male students. Aslan (2009) and Ceyhan (2014) conducted similar studies and found that the reflective thinking level differed in favor of women by gender. 
In the study conducted by Terzi and Mirasyedioğlu (2009), male students' perceptions of mathematics self-efficacy were higher than female students' perceptions of mathematics self-efficacy. Pajares and Miller (1994), Junge, and Beverly (1995) stated that male students had higher mathematics self-efficacy perceptions than female students. On the other hand, it was stated that the perception of mathematics self-efficacy did not differ according to gender in favor of our study (Lent, Brown \& Larkin, 1984; Hackett, 1985; Cooper \& Robinson Debra, 1991).

Another finding obtained in the light of the analysis is the relationship between variables. There was a positive, statistically significant relationship between middle school students' reflective thinking skills towards problem-solving and mathematics selfefficacy perception. In the literature, there were rarely studies measuring the relationship between the two variables.

When the reflective thinking skills and self-efficacy perception of middle school students are evaluated according to the grade level, there was a significant mean difference between the $5^{\text {th }}$ and $8^{\text {th }}$-grade reflective thinking skills in favor of the $5^{\text {th }}$ grade. There was a significant mean difference between $5^{\text {th }}$ and $7^{\text {th }}$-grade self-efficacy perceptions in favor of the $5^{\text {th }}$ grade for self-efficacy perception. In this context, the higher the grade level, the more reflective thinking skills and self-efficacy.

\section{GiRiş}

Düşünme, insanları diğer canlılardan ayıran en önemli eylemlerden biridir. En genel anlamda düşünme, olaylar ve nesnelerin yerini alan simgeler arasında ilişki kurma olarak ifade edilebilir. Eleştirel, yaratıcı, cebirsel, somut, soyut, yansıtıcı gibi birçok forma sahip olan düşünme; bilgilerin kavramlara dönüştürüldüğü, analiz edildiği ve yorumlandığı zihinsel bir süreç olarak tanımlanabilmektedir (Saban, 2005). Özel düşünme şekillerini sıradan düşünceden farklı kılan en önemli özellik, düşünme sürecinde bireyin aktif, farkında ve otorite konumunda olmasıdır. Karar verme aşamasında yararlanılan zihinsel beceriler açısından birbirinden ayrılan özel düşünme biçimlerinden yansıtıcı düşünmenin fikir adamı John Dewey'dir. Düşünce ve uygulama noktasında eğitim ve öğretime dair önemli başarılara sahip ve öğrenci merkezli eğitim modeline önem veren Dewey'e (1933) göre yansıtma, belirli bir bilginin ve o bilginin olası sonuçlarının, onlara destek veren temeller ışığında aktif, kalıcı ve dikkatli bir biçimde algılanmasıdır. Dewey'in savunduğu yansıtıcı düşünmenin dört boyutu vardır (Ünver, 2003):

1.Yansıtıcı düşünmede görüş veya düşünceler arasındaki bağ hiyerarşik ve sistematiktir. Zincirin halkaları gibi birbirine bağlıdır. Bir görüş kendisinden önceki görüşten etkilenir ve kendisinden sonraki görüşü etkiler.

2.Yansıtıcı düşünmede tutum, duygu, inanç kavramları önem teşkil eder. Olumsuz duyguları olumluya çevirmek, olumlu duyguları geliştirmek önemli bir amaçtır.

3.Herhangi bir olgu, durum, düşünce mantık süzgecinden geçirilip onay alır veya reddedilir.

4.Yansıtıcı düşünme aktif, bilinçli ve tutarlı bir süreçtir.

Yansıtıcı düşünme birçok araştırmacı tarafından farklı şekillerde tanımlanmıştır. Schön'e (1987) göre bireyin kalıplaşmış bilgiler öğrenmesinden çok öğrenme yaşantılarının artmasını sağlayan süreçtir. Boyd ve Fales (1983) ise karşılaşılan bir problem hakkında içsel sorgulama süreci olarak tanımlar. Ünver (2003) ise bireyin öğrenme sürecinde olumlu ve olumsuz özelliklerinin farkına varıp problemleri çözmek için gerçekleştirilen düşünme süreci olarak belirtmiştir.

Düşünmenin aktif olarak işe koşulduğu diğer bir şekli problem çözmedir. Binghan (2004) tarafından problem çözme, bilgi ve becerilerden yararlanılarak problem çözümü için gerekli olan gayretin sarf edildiği, zihinsel bir işlem olarak açıklanmıştır. Kızılkaya ve Aşkar'a (2009) göre yansıtıcı düşünme bir problem durumu ile karşı karşıya kalındığında ortaya çıkar. Bu doğrultuda yansıtma en iyi problem çözme sürecinde gözlenebilir (Ülker, 2019). Yansıtıcı problem çözme çözüm sürecinde odaklanma, plan yapma, çözümleme, yorumlama, karar verme ve değerlendirme adımlarında yansıtıcı düşünmenin dâhil olduğu üst düzey düşünme tarzıdır. Bilişsel ve duyuşsal farkındalığın ön planda olduğu yansıtıcı düşünmede stratejiler geliştirilerek ne yapıldığı, neden yapıldığı, istenen sonuçlara nasıl ulaşılacağı düşünülerek en uygun yol tercih edilir. Problem çözümünde ve karar aşamasında yansıtıcı düşünme kişiye yardımcı pozisyondadır. Yaşanmışlıklar arttıkça; öğrencilerin analiz, sentez ve değerlendirme gibi üst düzey düşüncelere ulaşmaları kolaylaşacaktır. Bu araştırmalarda başarı sağlamak için kişinin üst seviye düşünme kültürüne ulaşabilmesi gerekmektedir. Bu da yansıtıcı düşünme yoluyla gerçekleşmektedir (Güney, 2008).

Bu alanda yapılan çalışmaları inceleyecek olursak, Ersözlü ve Kazu (2011) ortaokul beşinci sınıf öğrencilerinin yansıtıcı düşünmelerinin gelişimini sağlayan aktivitelerin sosyal bilgiler dersindeki başarılarına etkisi üzerine çalışmışlardır. Araştırma sonucunda elde edilen bulgular, yansıtıcı düşünme gelişimini sağlayan aktivitelerin bilgi seviyesinde değişikliğe yol açmadığıdır. Fakat kavrama, uygulama ve analiz seviyelerinde istatistiksel olarak anlamlı bir farklılığa sebep olduğunu belirtmektedir. Yıldız (2018) ilkokul dördüncü sınıf fen bilimleri dersinde yansıtıcı öğretim ile desteklenen basamaklı öğretimin ders başarısına ve derse karşı olan tutuma etkisini araştırmıştır. Deneysel çalışmasında kümeleme analizi yaparak deney ve kontrol grubunu oluşturmuştur. Deney ve kontrol grubunun başarı testi puanları arasında istatistiksel olarak anlamlı farklılık çıkmazken, grupların kendi içerisinde ön test - son teste göre doğru yanıtlarındaki artışa bakıldığında deney ile kontrol grubu öğrencileri arasında istatistiksel olarak anlamlı farklılık bulunmuştur. Tutum ölçeği incelendiğinde ise her iki gruba dâhil öğrencilerin puanlarının arttığı ancak gruplar arasında istatistiksel olarak anlamlı farklılığın olmadığı görülmüştür. Ayrıca deney grubunun, açık uçlu soruların çözümünde derste öğrendiklerini gerçek yaşama aktarmada daha başarılı oldukları gözlemlenmiştir. 
Baş ve Kıvılcım (2013) lise öğrencilerinin matematik ve geometri akademik başarılarının problem çözmeye yönelik yansıtıcı düşünme becerileri tarafından nasıl yordandığını incelemişlerdir. Benzer olarak Köseoğlu, Demirci, Demir ve Özyürek (2017) yedinci sınıfa devam eden öğrencilerin yansıtıcı düşünme becerilerini cinsiyet açısından incelemişlerdir. Yansıtıcı düşünmenin akademik başarıyı olumlu yönde yordadığı sonucuna ulaşmışlardır. Kaplan, Doruk ve Öztürk (2017) üstün yetenekli öğrencilerin yansıtıcı düşünme becerilerini problem çözme süreçlerinde nicel olarak incelemişlerdir. Karademir ve Görgün (2019) yansıtıcı düşünme becerileriyle birlikte öz-düzenleme becerilerini problem çözme durumlarında incelemişlerdir. Matematik öğretmeni adaylarının problem çözmeye karşı yansıtıcı düşünme becerileri (Kurtuluş ve Eryılmaz, 2017), sınıf öğretmeni adaylarının öğretmenlik uygulaması dersinde yansıtıcı düşünmeyi nasıl kullandıkları (Özbek ve Köse, 2018), ilköğretim matematik ve sınıf öğretmeni adaylarının yansıtıcı düşünme becerileri cinsiyete ve bölüme göre (Kandemir, 2015) incelenmiştir.

Öz yeterlik, son dönemde farklı disiplinlerde de sıklıkla kullanılan duyuşsal değişkenlerden biridir. Bireyin davranışlarının bilişsel, duyuşsal özellikler ve çevre faktörü ile şekillendiğini vurgulayan sosyal öğrenme kuramı öncüsü Bandura'nın davranış üzerine etkide bulunduğunu düşündüğü ana kavramlardan biri öz yeterliktir. Kişinin belli bir hedefe ulaşabilmesi amacıyla gerekli faaliyetleri planlayarak düzenleyip başarılı bir şekilde tamamlama kapasitesi algısı oluşturması öz yeterlik olarak adlandırılmıştır (Bandura, 1997). Senemoğlu (2005) öz yeterliği bireyin farklı durumların üstesinden gelmesine, başarma isteğine ve kapasitesine yönelik algısı, bilinci şeklinde tanımlamıştır. Bireyin özel durumlar dâhilinde kendi yetenek ve becerilerine ait olan güven duygusudur (Çağırgan Gülten, 2013). Bandura'ya (1986) göre, bir bireyin öz yeterlik algısına dört kaynak temel teşkil etmektedir. Bunlar;

1) Kişinin kişisel tecrübeleri, özellikle kişinin geçmişte yaşadığı başarı ve başarısızlıklar,

2) Başkalarının tecrübeleri; örneğin, benzer kişilerin davranışlarını model alarak onun tecrübelerini sergileme,

3) Sözel ikna; bireyin bir durumla karşı karşıya kaldığında başa çıkmak için aldığı tavsiyeler,

4) Duygusal durum; bir bireyin öz yeterliğini değerlendirirken kaygı, korku ve stres seviyesini dengede, kontrol altında tutabilmesidir.

Öz yeterlikle ilgili araştırmalar incelendiğinde genellikle psikoloji ve eğitim alanında yapıldığı görülmektedir. Fakat günümüzde disiplinler arası ilişkilerin önem kazandığı ve sorunların birçok boyuttan ele alındığı düşünüldüğünde matematik eğitimi alanında da öz yeterlikle ilgili araştırmalar bulunmaktadır. Matematik öz yeterliği Pajares (1996) tarafından kişinin matematik problemini başarıyla bitirebilme yeteneğine olan inancın ve özgüvenin değerlendirilmesi olarak tanımlanmıştır. Matematik öz yeterliğinin ders başarısını etkileyen faktörler arasında olduğu düşünülmektedir. Çünkü öz yeterlik ne kadar kuvvetli olursa, bireyde o kadar çok gayret, güç, ısrar, sabır ve direnç olur. Bu da dolaylı olarak akademik başarısına yansır. Öz yeterlik aynı zamanda kişilerin düşünme tarzını, problem çözme yetilerini duygusal açıdan etkilemektedir. Öz yeterliği düşük olan kişiler olaylara tek bir pencereden bakarak, karşılaştıkları problemlere olumsuz olarak yaklaşıp çözemezler. Öte yandan öz yeterliği yüksek bireyler olaylara daha olumlu yaklaşıp zor durumlarda bile rahat ve güvenli hareket ederler (Kaptan ve Korkmaz, 2001). Schunk (1989) öz yeterlikleri yüksek olan öğrencilerin, bir işi başarılı olarak tamamlamada öz yeterlikleri düşük olan öğrencilere kıyasla daha çok gayret gösterdikleri ve dirençli olarak çalıştıklarını ifade etmiştir. Bu sonuç Kaptan ve Korkmaz'ın (2001) bulgularını destekler niteliktedir. Doruk, Öztürk ve Kaplan (2016) ortaokul öğrencilerinin matematiğe yönelik öz yeterlik algılarını çeşitli değişkenlerle incelemişlerdir. Özgen ve Bayram (2020) ortaokula devam eden öğrencilerin problem kurma becerilerini ve öz-yeterlik inançlarını cinsiyet, sınıf seviyesi ve akademik başarı değişkenlerinde incelemişlerdir.

Yapılan araştırmalar incelendiğinde problem çözmeye yönelik yansıtıcı düşünme becerisi ve matematik öz yeterlik algısına ait ayrı ayrı çalışmalar mevcut olmasına rağmen iki konunun birlikte çalışıldığı ve aralarındaki ilişkiyi inceleyen herhangi çalışmaya rastlanmamıştır. Bu sebeple gerçekleştirilen bu araştırmada ortaokul öğrencilerinin problem çözmeye yönelik yansıtıcı düşünme becerileri ile matematik öz yeterlik algıları çeşitli değişkenler açısından incelenmiştir. Araştırmadan elde edilecek bulgular alan yazında var olan çalışmaların güvenirlik ve geçerliliğini güçlendirmesi ve ilgili alandaki boşluğu gidermesi bakımından önem arz etmektedir.

\section{Araştırmanın amacı}

Bu araştırmanın amacı, ortaokul öğrencilerinin problem çözmeye yönelik yansıtıcı düşünme becerisi ile matematik öz yeterlik algılarının bazı değişkenlere göre değişip değişmediğini incelemek ve yansıtıcı düşünme becerisi ile matematik öz yeterlik algı düzeylerini değerlendirebilmektir. Ayrıca yansıtıcı düşünme becerisi ve matematik öz yeterlik algısı arasında anlamlı ilişki olup olmadığını incelemek de amaçlanmıştır. Bu araştırmanın problemi: ortaokul öğrencilerinin problem çözmeye yönelik yansıtıcı düşünme becerileri ile matematik öz yeterlik algılarının bazı faktörlerden etkilenip etkilenmediğinin araştırılmasıdır. Bu araştırmanın problemi: "Ortaokul öğrencilerinin problem çözmeye yönelik yansıtıcı düşünme becerileri ile matematik öz yeterlik algıları bazı faktörlerden etkilenmekte midir?". Bu araştırmanın alt problemleri:

•Ortaokul öğrencilerinin problem çözmeye yönelik yansıtıcı düşünme becerileri ve öz yeterlik algıları ne düzeydedir?

- Cinsiyetlerine göre problem çözmeye yönelik yansıtıcı düşünme becerileri ve öz yeterlik algılarında farklılık var mıdır?

•Ortaokul öğrencilerinin problem çözmeye yönelik yansıtıcı düşünme becerileri ile matematik öz yeterlik algıları arasında anlamlı ilişki var mıdır?

•Sınıf düzeylerine göre problem çözmeye yönelik yansıtıcı düşünme becerileri ve öz yeterlik algılarında farklılık var mıdır? 
•Karne notlarına göre problem çözmeye yönelik yansıtıcı düşünme becerileri ve öz yeterlik algılarında farklıık var mıdır?

\section{YÖNTEM}

\section{Araştırma modeli}

Araştırma genel tarama modelinde betimsel ve ilişkisel bir çalışmadır. Betimsel çalışma geçmiş veya günümüzde karşılaştığımız bir problemin görünür haliyle tasvir edildiği araştırma yaklaşımıdır. Çalışmaya dâhil olan olay, kişi veya nesne kendi şartları göz önünde bulundurularak ve var olduğu şekliyle betimlenmeye çalışılır (Karasar, 2012). iliş̧isel tarama modeli ise iki veya daha çok değişkenin bir arada değişim derecesini saptamaya çalışan modeldir (Karasar, 2012). Bu yöntem aracılığıyla ortaokul öğrencilerinin problem çözmeye yönelik yansıtıcı düşünme becerileri ile matematik öz yeterlik algılarının sınıf seviyesi, cinsiyet ve karne notu gibi değişkenlerle olan ilişkisi ve bağımlı değişkenlerin kendi içinde ilişkisi incelenerek açıklanmıştır.

\section{Evren Örneklem}

Araştırmanın evreni Kayseri ili Kocasinan ilçesi ortaokul öğrencileri olarak belirlenmiştir. Araştırmanın örneklemini, 2019-2020 eğitim öğretim yılı, Kocasinan ilçesinde bulunan sosyo-ekonomik ve sosyo-kültürel şartlar bakımından orta düzey bir devlet okulunun 5, 6, 7 ve 8. sınıfında öğretim alan öğrenciler oluşturmaktadır. Araştırma probleminin amacına uygun olarak seçilen ve Tablo 1'de ayrıntılı olarak verilen toplam 421 öğrenci ile çalışılmıştır. Araştırma dâhilinde seçkisiz olmayan örnekleme yöntemlerinden, uygun örnekleme yöntemi tercih edilmiştir. Uygun örnekleme yöntemi; ulaşılması kolay, elde hazır bulunan ve araştırmaya katılmak isteyen (gönüllü) bireyler üzerinden yapılan örneklemedir (Christensen, Johnson ve Turner, 2015). Eğitim araştırmalarında çoğu zaman seçkisiz veya sistematik bir örneklem seçmek oldukça zor, bazen de imkânsız olabilmektedir. Bu gibi durumlarda, bir araştırmacı uygun örnekleme yöntemini kullanabilir. Uygun örneklem araştırmacının erişebildiği ve araştırma yapılmasına izin verilen ikinci araştırmacının görev yaptığı okuludur. Tablo 1'de örneklemin sınıf düzeyine ve cinsiyete göre dağılımları verilmiştir.

Tablo 1. Sınıf düzeyine ve cinsiyete ait frekans tablosu

\begin{tabular}{|c|c|c|c|}
\hline Değişkenler & & $f$ & $\%$ \\
\hline \multirow{4}{*}{ Sınıf Düzeyi } & 5 & 77 & 18,3 \\
\hline & 6 & 83 & 19,7 \\
\hline & 7 & 120 & 28,5 \\
\hline & 8 & 141 & 33,5 \\
\hline \multirow{2}{*}{ Cinsiyet } & KIZ & 223 & 53 \\
\hline & Erkek & 198 & 47 \\
\hline
\end{tabular}

\section{Veri toplama araçları}

Bu çalışmada problem çözmeye yönelik yansıtıcı düşünme becerisi ve matematik öz yeterlik algısı ölçekleri kullanılmıştır. Kızılkaya ve Aşkar (2009) tarafından geliştirilen yansıtıcı düşünmeyi açığa çıkaran eylemlerin analiz edilerek sorgulama, nedenleme ve değerlendirme olmak üzere üç alt boyutunu belirlemeyi amaçlayan ölçek, güvenirlik ve geçerlik çalışmalarından önce 14 maddeden oluşmaktadır. Ölçek, ilköğretim yedinci sınıfta öğrenim gören 174 kız ve 165 erkek olmak üzere toplamda 339 öğrenciye uygulanmış ve istatistiksel olarak analiz edilmiştir. Elde edilen veriler doğrulayıcı faktör analizi ile yorumlanarak verilerin uygunluğu tespit edilmiştir. Yansıtıcı düşünme becerisi ölçeğinin geçerlik için doğrulayıcı faktör analizi sonucu uyum indeksleri CFI= 0,95, GFI= $0,92, \mathrm{NNFI}=0,93, \mathrm{RMSR}=0,08, \mathrm{AGFI}=0,89, \mathrm{RMSEA}=0,071$ olarak bulunmuştur. Bu araştırma kapsamında faktörlerin dağılımının aynı olup olmadığına bakıımak için faktör analizi yapılmıştır. Faktör dağılımı aynı olduğunda analizlere faktör puanları kullanılarak devam edilecektir. Faktörler aynı dağılım göstermediğinde toplam puanlar üzerinden analiz yapılacaktır.

Araştırmada Umay (2001) tarafından geliştirilen Matematiğe Karşı Öz Yeterlik Algısı Ölçeğinden yararlanılmıştır. Matematik benlik algıSı, matematik konularında davranışlarındaki farkındalık ve matematiği yaşam becerilerine dönüştürebilme olmak üzere üç alt faktörden meydana gelen ölçek 14 maddeden oluşmaktadır. Ölçeğin güvenirlik katsayısı 0,88, ölçek maddelerinin geçerlik katsayılarının medyanı 0,64 olarak bulunmuştur. Bu medyan değerinin ölçeğin tamamı için geçerlik sağlayabileceği düşünülmüştür.

Tablo 2'de incelenen yansıtıcı düşünme becerisi ve matematik öz yeterlik algısını ölçen maddelerin Cronbach Alpha güvenirlik katsayısı sırası ile 0,810 ve 0,844 bulunmuştur. Bu değerler 0,70'ten büyük olduğu için güvenirlik katsayısının yeterli düzeyde olduğu yani bu maddelerden elde edilen puanların güvenilir olduğu kararına varılabilir (Akbulut, 2010). Ayrıca elde edilen bu değerler, ölçekleri geliştiren Kızılkaya ve Aşkar (2009) ile Umay'ın (2001) bulduğu güvenirlik katsayıları ile örtüşmektedir.

Tablo 2.Yansıtıcı düşünme becerisi ve öz yeterlik algısı ölçeğinin güvenirlik katsayıları

\begin{tabular}{lccc}
\hline Anket & \multirow{2}{*}{ Cronbach's Alpha } & Standardize Edilmiş Maddelere Dayalı Cronbach's & Alpha \\
\hline Yansıtıcı düşünce becerisi &, 810 &, 812 & 14 \\
Öz yeterlik algısı &, 844 &, 846 & 14 \\
\hline
\end{tabular}

Ortaokul öğrencilerinin problem çözmeye yönelik yansıtıcı düşünme becerileri ve öz yeterlik algılarının faktör analizi 
Determinant değeri 0,074 olan problem çözmeye yönelik yansıtıcı düşünme becerisi ölçeğinin 0,00001 determinant değerinden büyük olması, KMO değeri $p=0,871^{\prime}$ in 0,60'tan büyük olması ve Bartlett'in Küresellik testi sonucu p=0,000'ın 0,05 değerinden küçük olması mevcut verilerin faktör analizine uygun olduğunu göstermektedir. Yapılan analiz sonucu her bir faktör altında bulunan maddeler aynı olmamasına rağmen, Kızılkaya ve Aşkar (2009) tarafından bulunan faktör sayısı bu çalışmada da elde edilmiştir. Şekil 1'de verilen yamaç birikinti grafiğindeki çizginin yatay konum almadan önceki keskin düşüşlerinin sayısı dikkate alındığında, üç faktörlü yapının uygun olduğu ve istenirse Tablo 3'te önerilen üç faktörlü yapının da kullanılabileceği görülmektedir.

Tablo 3. Problem çözmeye yönelik yansıtıcı düşünme becerisi ölçeği döndürülmüş bileşen matrisi

\begin{tabular}{|c|c|c|}
\hline $\begin{array}{c}\text { Maddeler } \\
\end{array}$ & 1. Faktör & 2. Faktör 3. Faktör \\
\hline “2. Problemi çözdükten sonra daha iyi bir çözüm yolu bulabilir miyim diye düşünürüm.” & ,707 & \\
\hline “6. Bir problemi çözdüğümde, yaptığım işlemleri tekrar inceler, değerlendiririm." & ,625 & \\
\hline "10. Problemi çözüp sonucunu bulduktan sonra yaptığım işlemleri kontrol ederim." &, 564 & \\
\hline “7. Problem çözerken, farklı çözüm yolları bulmak için kendime sorular sorarım.” & ,555 & \\
\hline "4. Çözüm yollarımı tekrar tekrar değerlendirip bir sonraki problemi daha iyi çözmeye çalışırım." & ,523 & \\
\hline “14. Problemi çözdükten sonra arkadaşlarımın çözümleri ile karşılaştırır, sonucumu değerlendiririm.” & & ,725 \\
\hline “1. Bir problemi çözemediğimde, neden çözemediğimi anlamak için kendime sorular sorarım.” & & ,543 \\
\hline “8. Problem çözerken, yaptığım işlemlerin nedenini düşünerek, bulduğum sonuçla ilişkisini kurmaya çalışırım.” & & ,537 \\
\hline $\begin{array}{l}\text { "11. Bir problemi okuduğumda, daha önce çözdüğüm problemleri düşünerek benzerlik ve farklılıklarına göre } \\
\text { aralarında ilişki kurarım." }\end{array}$ & & ,492 \\
\hline “3. Arkadaşlarımın çözüm yollarını sorgulayarak daha iyi bir yol bulmaya çalışırım.” & & ,444 \\
\hline "9. Bir problemi okuduğumda, çözüm için hangi bilgiye ihtiyacım olduğunu düşünürüm.” & & 735 \\
\hline “5. Problem çözerken, hangi işlemi neden yaptığımı düşünerek yaparım.” & &, 545 \\
\hline “12. Problem çözerken, her işlemimi önceki ve sonraki adımlarımı düşünerek yaparım.” & &, 513 \\
\hline "13. Problemi okuduğumda verilen ve istenenleri belirlemek için kendime sorular sorarım." & & ,478 \\
\hline
\end{tabular}

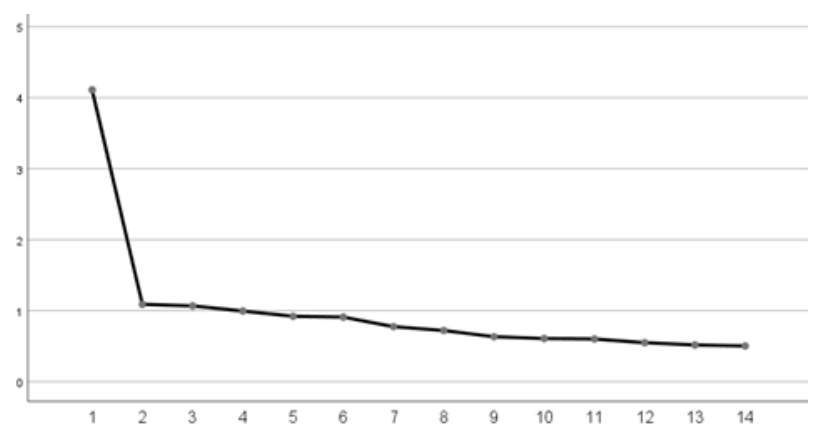

Şekil 1. Yansıtıcı düşünme becerisi ölçeğinde bulunan maddelere ait yamaç birikinti grafiği

Determinant değeri 0,020 olan matematik öz yeterlik algısı ölçeğinin p=0,00001 determinant değerinden büyük olması, KMO değeri $p=0,890$ 'nın 0,60'tan büyük olması ve Bartlett'in Küresellik testi sonucu $p=0,000$ 'ın 0,05 değerinden küçük olması mevcut verilerin faktör analizine uygun olduğunu göstermektedir. Yapılan analiz sonucu her bir faktör altında bulunan maddeler aynı olmamasına karşın, Umay (2001) tarafından bulunan faktör sayısı bu çalışmada da bulunmuştur. Şekil 2'de verilen yamaç birikinti grafiğindeki çizginin yatay konum almadan önceki dirseklerin sayısı dikkate alındığında, üç faktörlü yapının uygun olduğu görülmektedir. Tablo 4'te verilen faktör sayısı da grafiği destekler niteliktedir.

Tablo 4. Matematik öz yeterlik algısı ölçeği döndürülmüş bileşen matrisi

\begin{tabular}{|c|c|c|c|}
\hline Maddeler & 1. Faktör & 2. Faktör & 3. Faktör \\
\hline “11. Problem çözmekle geçirdiğim zamanların büyük bölümünü kayıp olarak görüyorum.” & ,750 & & \\
\hline “3. Matematiğin benim için uygun bir uğraş olmadığını düşünüyorum.” & 679 & & \\
\hline "10. Matematiğe çevremdekiler kadar hâkim olmanın benim için imkansız olduğuna inanırım." & 668 & & \\
\hline “1. Matematiği günlük yaşamımda etkin olarak kullanabildiğimi düşünüyorum.” & 646 & & \\
\hline “5. Yeterince uğraşırsam her türlü matematik problemini çözebilirim.” & ,559 & & \\
\hline "12. Matematik çalışırken kendime olan güvenimin azaldığını fark ediyorum." &, 531 & & \\
\hline “4. Matematikte problem çözme konusunda kendimi yeterli hissediyorum.” & ,469 & & \\
\hline "14. Yaşam içindeki her türlü probleme matematiksel yaklaşımla çözüm önerileri getirebilirim." & & 765 & \\
\hline “8. Matematiksel yapılar ve teoremler içinde dolaşıp yeni, küçük keşifler yapabilirim.” & & ,727 & \\
\hline “13. Matematikle ilgili sorunlarında çevremdekilere kolaylıkla yardım edebilirim.” & & ,604 & \\
\hline “2. Günümü/zamanımı planlarken matematiksel düşünürüm.” & & ,557 & \\
\hline “9. Matematikte yeni bir durumla karşılaştığımda nasıl davranmam gerektiğini bilirim.” & &, 516 & \\
\hline “7. Problem çözerken beklenmedik bir durumla karşılaştığımda telaşa kapııırım.” & & & ,815 \\
\hline "6. Problem çözerken yanlış adımlar atıyorum duygusu taşırım." & & & ,786 \\
\hline
\end{tabular}




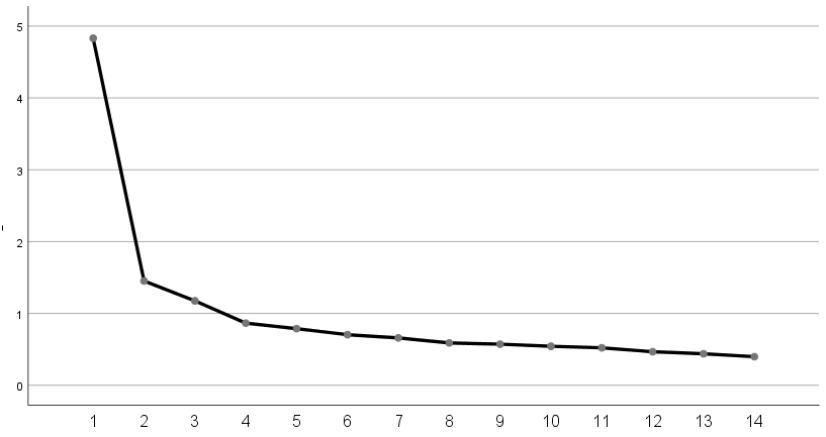

Şekil 2. Öz yeterlik algısı ölçeğinde bulunan maddelere ait yamaç birikinti grafiği

\section{Verilerin analizi}

Yansıtıcı düşünme becerisi ölçeğini oluşturan olumlu maddeler "Her zaman" seçeneğinden başlayıp, "Hiçbir zaman" seçeneğine doğru 5'ten 1'e doğru puanlandırııırken, olumsuz maddeler ise 1'den 5'e doğru puanlandırılmışıı. Öğrencilerin ölçekten alabileceği en yüksek puan 70, en düşük puan ise 14 olup, ölçekten elde edilen toplam puanı yüksek öğrencinin yansıtıcı düşünme becerisinin yüksek olduğu şeklinde yorumlanmışır. Matematik öz yeterlik algısı ölçeğini oluşturan olumlu maddeler "Kesinlikle katılıyorum" seçeneğinden başlayıp, "Kesinlikle katılmıyorum" seçeneğine doğru 5'ten 1'e doğru puanlandırılırken, olumsuz maddeler ise 1'den 5’e doğru puanlandırılmıştır. Bir önceki ölçekte olduğu gibi 14 maddeden oluşan ölçekten yüksek puan alan öğrencinin matematik öz yeterlik algısının yüksek olduğu düşünülmektedir. Ölçeklerden elde edilen bulgular nicel olarak incelenerek değerlendirilmiştir. Veriler analiz edilirken istatistiksel işlemler için SPSS 25 kullanılmışıı. Ortaokul öğrencilerinin yansıtıcı düşünme becerileri ve öz yeterlik algısı puanları ile cinsiyet, sınıf seviyesi ve karne notu arasında istatistiksel olarak anlamlı fark olup olmadığının araştıııması için öncelikli olarak verilerin normal dağılım gösterip göstermediği hakkında bilgi veren Kolmogorov-Smirnov testi ve betimsel istatistik değerleri ile histogramlar incelenmiştir. Daha sonra ise bu doğrultuda ortaokul öğrencilerinin yansıtıcı düşünme becerileri ile matematik öz yeterlik algılarının; cinsiyete göre istatistiksel olarak anlamlı farklılık oluşturup oluşturmadığı Mann Whitney U ile sınıf düzeyi ve karne notuna göre istatistiksel olarak anlamlı farklılık oluşturup oluşturmadığı ise Kruskal Wallis ile değerlendirilmiştir. Öğrencilerin problem çözmeye yönelik yansıtııı düşünme becerileri ile matematik öz yeterlik algıları arasındaki ilişki ise Spearman Korelasyonu kullanılarak incelenmiştir.

\section{Etik Konular}

Bu araştırmada kullanılan veri toplama araçlarının etik açıdan kontrolü Erciyes Üniversitesi Sosyal ve Beşerî Bilimler Etik Komitesi tarafından 25 Şubat 2020 tarihi toplantııında yapıImışır ve 25 Şubat 2020 tarihi 24 numaralı etik kurul inceleme raporuyla verilmiştir.

\section{BULGULAR}

Bu bölümde uygulanan problem çözmeye yönelik yansıtıcı düşünme becerisi ölçeği ve matematik öz yeterlik algısı ölçeğinden elde edilen veriler üzerinde yapılan istatistiksel analizlere yer verilmiştir. Ortaokul öğrencilerinin yansıııcı düşünme becerilerinin ve öz yeterlik algılarının cinsiyete, sınıf düzeyine ve karne notuna göre farklılık gösterip göstermediğini açığa çıkarmak için öncelikli olarak verilerin normal dağılıp dağılmadığının öğrenilmesi amacıyla Kolmogorov-Smirnov Testi'nden yararlanılmışır. Yansıtıcı düşünme becerisi ölçeği iç̧in $(p=, 000<0,05)$ ve öz yeterlik algısı ölçeğinde $(p=, 000<0,05)$ olduğu tespit edilmiştir. Bu durum grupların normal dağılmadığını göstermektedir. Dolayısıyla parametrik olmayan testler kullanılmıştır. Ayrıca yansııııı düşünme becerisi ve öz yeterlik algısı puanlarına ait betimsel değerler Tablo 5'te, histogramlar ise Şekil 3'te verilmiştir.

Tablo 5. Yansıtıcı düşünme becerisi ve öz yeterlik algısına ait toplam puanların betimsel değerleri

\begin{tabular}{lcc}
\hline İstatistik & Yansıtııı Düşünme Becerisi & Öz Yeterlik Algısı \\
\hline Ortalama & 51,8409 & 50,0404 \\
Medyan & 53 & 51 \\
Mod & 53 & 54 \\
Standart sapma & 8,31441 & 9,80188 \\
Varyans & 69,129 & 96,077 \\
Çarpıklık katsayısı &,- 457 &,- 620 \\
Basıklık katsayısı &,- 006 &, 252 \\
Açıklık & 46 & 50 \\
En küçük değer & 24 & 20 \\
En büyük değer & 70 & 70 \\
\hline
\end{tabular}



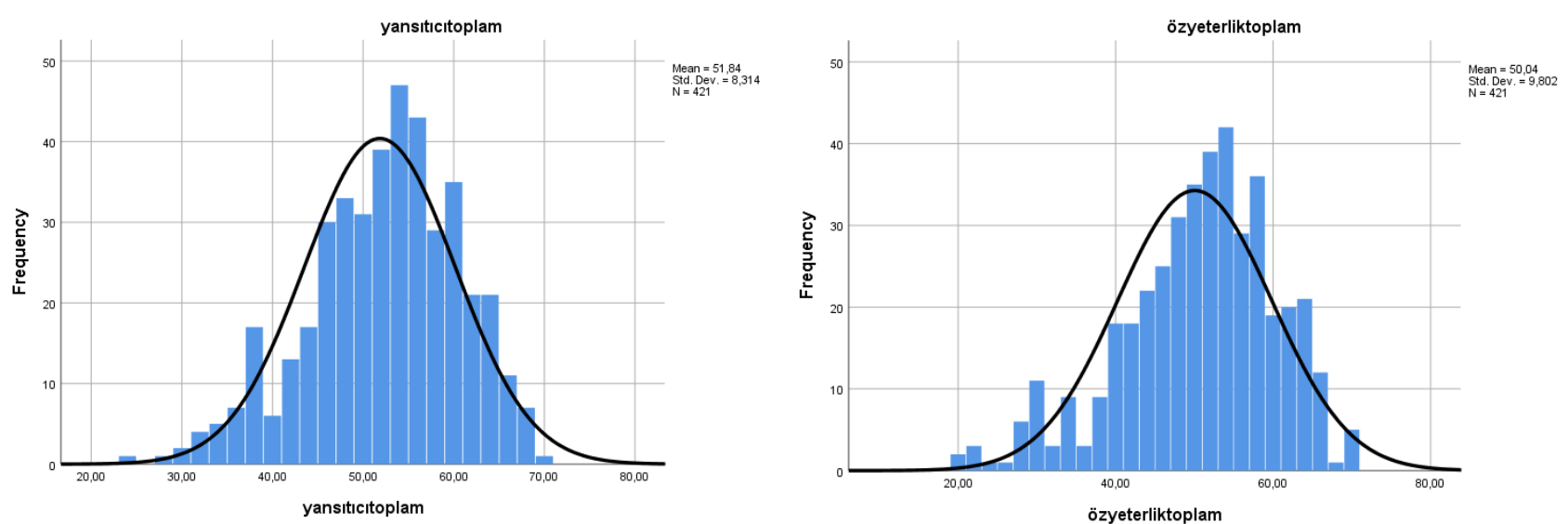

Şekil 3. Yansıtıcı düşünme becerisi ve öz yeterlik algısı ölçeğine ait histogramlar

\section{Ortaokul öğrencilerinin problem çözmeye yönelik yansıtıcı düşünme becerileri ile öz yeterlik algı düzeyleri}

Ortaokul öğrencilerinin yansıtıcı düşünme becerileri ve öz yeterlik algılarına ilişkin betimsel değerler ele alındığında, ortaokul öğrencilerinin yansıtıcı düşünme becerisi puanlarının betimsel değerleri ( $\bar{X}=51,84, S S=8,31$ ) ölçekten alınabilecek puan

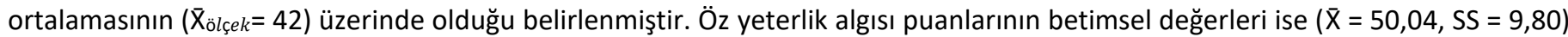
yine ölçekten alınabilecek puan ortalamasının $\left(\bar{X}_{\text {ölçek }}=42\right)$ üzerinde olduğu görülmüştür. Bu değerlere göre ortaokul öğrencilerinin yansıtıcı düşünme becerileri ve öz yeterlik algılarının ortalamanın üstünde, yüksek bir değere sahip olduğu belirtilebilir.

\section{Ortaokul öğrencilerinin cinsiyetlerine göre problem çözmeye yönelik yansıtıcı düşünme becerileri ve öz yeterlik algıları}

Ortaokul öğrencilerinin yansıtıcı düşünme becerileri ile öz yeterlik algılarının cinsiyete göre anlamlı olarak farklılaşıp farklılaşmadığının araştırılması için öncelikle normal dağılım varsayımı hakkında bilgi veren Kolmogorov-Smirnov testi uygulanmıştır. Yansıtıcı düşünme becerisine ait $p$ değerlerinin kızlar için $(p=, 004)$, erkekler için $(p=, 022)$ ve öz yeterlik algısına ait $p$ değerlerinin kızlar için $(p=, 014)$, erkekler için $(p=, 002) 0,05$ değerinden küçük olması normal dağılım varsayımını sağlamamaktadır. Ortaokul öğrencilerinin cinsiyete göre yansıtıcı düşünme becerileri ve öz yeterlik algısına ilişkin betimsel bulguları Tablo 6'da sunulmuştur. Parametrik olmayan testlerden Mann Whitney U testi yapılarak sonuçları Tablo 7 ve Tablo 8'de gösterilmiştir.

Tablo 6. Cinsiyete göre yansıtıcı düşünme becerisi ve öz yeterlik algısı puanlarının betimsel değerleri

\begin{tabular}{|c|c|c|c|}
\hline Cinsiyet & İstatistik & Yansıtıcı Düşünme Becerisi & Öz Yeterlik Algısı \\
\hline \multirow[t]{9}{*}{$\mathrm{K} ı \mathrm{z}$} & Ortalama & 52,2915 & 49,9731 \\
\hline & Medyan & 53 & 51 \\
\hline & Varyans & 67,883 & 103,107 \\
\hline & Standart sapma & 8,23912 & 10,15418 \\
\hline & Minimum & 24 & 20 \\
\hline & Maksimum & 68 & 70 \\
\hline & Açıklık & 44 & 50 \\
\hline & Çarpıklık &,- 502 &,- 594 \\
\hline & Basıklık & ,118 & ,051 \\
\hline \multirow[t]{9}{*}{ Erkek } & Ortalama & 51,3333 & 50,1162 \\
\hline & Medyan & 52 & 51 \\
\hline & Varyans & 70,396 & 88,631 \\
\hline & Standart sapma & 8,39023 & 9,41441 \\
\hline & Minimum & 28 & 20 \\
\hline & Maksimum & 70 & 70 \\
\hline & Açıklık & 42 & 50 \\
\hline & Çarpıklık &,- 411 &,- 654 \\
\hline & Basıklık &,- 093 &, 552 \\
\hline Anket & Cinsiyet & Sira & Sıralar Toplamı \\
\hline \multirow[t]{2}{*}{ Yansıtıcı Düşünme Becerisi } & $\mathrm{K} I \mathrm{Z}$ & 223 & 48479 \\
\hline & Erkek & 198 & 40352 \\
\hline \multirow[t]{2}{*}{ Öz Yeterlik Algısı } & $\mathrm{KIz}$ & 223 & 47128 \\
\hline & Erkek & 198 & 41703 \\
\hline
\end{tabular}


Tablo 8. Cinsiyet değişkenine göre yansıtıcı düşünme becerisi ve öz yeterlik algısı puanlarına Ait Mann Whitney U testi

\begin{tabular}{lll}
\hline İstatistik & Yansıtıcı Düşünme Becerisi & Öz Yeterlik AlgıSı \\
\hline Mann-Whitney U & 20651 & 22002 \\
$z$ & $-1,145$ &,- 060 \\
$p$ &, 252 &, 952 \\
\hline
\end{tabular}

Cinsiyete göre öğrencilerinin yansıııcı düşünme becerileri arasında istatistiksel olarak anlamlı farklılık olmadığı görülmüştür [Mann Whitney $U=20651 ; z=-1,145 ; p=0,252$ ]. Yansıtıcı düşünme becerisinde olduğu gibi öğrencilerin öz yeterlik algıları da cinsiyete göre istatistiksel olarak anlamlı farklılık göstermemektedir [Mann Whitney $U=22002 ; z=-0,060 ; p=0,952$ ]. Bu sonuca göre kız öğrencilerle erkek öğrencilerin yansıtıcı düşünme becerileri ve matematik öz yeterlik algılarında önemli düzeyde bir değişmenin gerçekleşmediğini söylemek mümkündür.

\section{Ortaokul öğrencilerinin problem çözmeye yönelik yansıtıcı düşünme becerileri ile öz yeterlik algıları arasındaki ilişki}

Ortaokul öğrencilerinin yansıııcı düşünme becerileri ile öz yeterlik algıları arasındaki ilişkinin ortaya çıkarılması amacıyla, iki ölçekten elde edilen toplam puanların $p$ değerlerine göre normal dağııım varsayımı kabul edilmediği için Spearman Korelasyonu kullanılarak incelenmiştir. Buna göre ortaokul öğrencilerinin yansıııcı düşünme becerisi ölçeğinden aldıkları toplam puanlar ile öz yeterlik algısı ölçeğinden aldıkları toplam puanlar arasında orta düzeyde, pozitif ve istatistiksel anlamlı bir ilişki $(r=0,383 ; n=421$; $p=0,00$ ) olduğu görülmüştür. Dolayısıyla öğrencilerin yansıtıcı düşünme becerileri arttıkça öz yeterlik algılarının da arttığı söylenebilir.

\section{Ortaokul öğrencilerinin sınıf düzeylerine göre problem çözmeye yönelik yansıtıcı düşünme becerileri ve öz yeterlik algıları}

Ortaokul öğrencilerinin yansıtıcı düşünme becerilerinin ve öz yeterlik algılarının sınıf seviyelerine göre farklılık gösterip göstermediğini açığa çıkarmak için öncelikli olarak normal dağııı varsayımı hakkında bilgi veren Kolmogorov-Smirnov testi uygulanmıştır. Yansıtıcı düşünme becerisi ölçeğinde beşinci sınıfa ait $p$ değeri $(p=, 200)$, altıncı sınıfa ait $p$ değeri $(p=, 072)$ ve yedinci sınıfa ait $p$ değeri $(p=, 200) 0,05$ değerinden büyük olmasına rağmen sekizinci sınıfa ait $p$ değerinin $(p=, 002) 0,05$ değerinden küçük olması normal dağııım varsayımını sağlayamamaktadır. Öz yeterlik algısı ölçeğinde ise altıncı sınıfa ait $p$ değeri $(p=, 181)$, sekizinci sınıfa ait $p$ değeri $(p=, 200) 0,05$ değerinden büyük olmasına rağmen beşinci sınıfa ait $p$ değeri $(p=, 001)$ ve yedinci sınıfa ait $p$ değerinin ( $p=, 000) 0,05$ değerinden küçük olması normal dağııım varsayımını göstermemektedir. Dolayısıyla parametrik olmayan testlerden Kruskal Wallis testi kullanılmıştır. Sınıf düzeyine göre yansıtııı düşünme becerisi ve öz yeterlik algısı puanlarına ait betimsel değerler Tablo 9'da sunulmuştur.

Tablo 9. Sınıf düzeyine göre yansıtıcı düşünme becerisi ve öz yeterlik algısı puanlarının betimsel değerleri

\begin{tabular}{|c|c|c|c|}
\hline Sınıf & İstatistik & Yansıtıcı Düşünme Becerisi & Öz Yeterlik Algısı \\
\hline \multirow[t]{9}{*}{ 5. $\sin I f$} & Ortalama & 54,0649 & 52,1299 \\
\hline & Medyan & 54 & 54 \\
\hline & Varyans & 80,404 & 125,614 \\
\hline & Standart sapma & 8,96681 & 11,20779 \\
\hline & Minimum & 24 & 21 \\
\hline & Maksimum & 70 & 70 \\
\hline & Açıkıı & 46 & 49 \\
\hline & Çarpıklık &,- 706 &,- 953 \\
\hline & Basıklık & ,685 & 239 \\
\hline \multirow[t]{9}{*}{ 6. sinıf } & Ortalama & 52 & 50,7108 \\
\hline & Medyan & 53 & 52 \\
\hline & Varyans & 76,659 & 81,208 \\
\hline & Standart sapma & 8,75549 & 9,01155 \\
\hline & Minimum & 28 & 30 \\
\hline & Maksimum & 67 & 70 \\
\hline & Açıklık & 39 & 40 \\
\hline & Çarpıklık &,- 572 &,- 207 \\
\hline & Basıklık &,- 236 &,- 072 \\
\hline \multirow[t]{9}{*}{ 7. $\sin I f$} & Ortalama & 51,3750 & 49,0833 \\
\hline & Medyan & 51,5000 & 51 \\
\hline & Varyans & 59,110 & 90,632 \\
\hline & Standart sapma & 7,68832 & 9,52007 \\
\hline & Minimum & 29 & 20 \\
\hline & Maksimum & 68 & 66 \\
\hline & Açıklık & 39 & 46 \\
\hline & Çarpıklık &,- 198 &,- 980 \\
\hline & Basıklık & ,208 & 1,022 \\
\hline
\end{tabular}




Ortalama
Medyan
Varyans
Standart sapma
Minimum
Maksimum
Açıklık
Çarpıklık
Basıklık

50,9291
52
64,838
8,05219
29
66
37
,- 567
,- 232

49,3191

49

91,462

9,56356

22

70

48

$-, 403$

$-, 017$

Yapılan Kruskal Wallis testinde yansıtıcı düşünme becerisi için hesaplanan anlamlılık değeri $p=0,033<0,05$ olduğundan öğrencilerin yansıtıcı düşünme becerilerinin sınıf seviyesine göre istatistiksel olarak anlamlı farklılık gösterdiği kararına varılabilir $\left[X^{2}(3, n=421)=8,726 ; p=0,033\right]$. Öz yeterlik algısı için hesaplanan anlamlılık değeri $p=0,027<0,05$ olduğundan öğrencilerin öz yeterlik algılarının da sınıf seviyesine göre istatistiksel olarak anlamlı farklılık gösterdiği söylenebilir $\left[X^{2}(3, n=421)=9,155 ; p=0,027\right]$. Alt gruplar arasındaki farklııkların tespiti için parametrik olmayan testlerden iki bağımsız örneklemi karşılaştıran Mann Whitney $U$ testi kullanılmıştır. Tablo 10 'da Kruskal Wallis $\mathrm{H}$ testi sonrası ikili karşılaştırmalar verilmiştir.

Tablo 10. Kruskal Wallis H testi sonrası ikili karşılaştırmalar (Mann Whitney U Testi istatistiği)

\begin{tabular}{|c|c|c|c|c|c|c|}
\hline \multirow{2}{*}{ Sinıflar } & \multicolumn{3}{|c|}{ Yansıtıcı Düşünme Becerisi } & \multicolumn{3}{|c|}{ Öz Yeterlik Algısı } \\
\hline & $U$ & $z$ & $p$ & $U$ & $z$ & $p$ \\
\hline $5-6$ & 2767 & $-1,465$ & 143 & 2689,5 & $-1,729$ & 084 \\
\hline $5-7$ & 3629,5 & $-2,539$ & 011 & 3538 & $-2,773$ & ,006 \\
\hline $5-8$ & 4225 & $-2,706$ & ,007 & 4269,5 & $-2,605$ & 009 \\
\hline $6-7$ & 4578,5 &,- 977 & 329 & 4612 &,- 895 & 371 \\
\hline $6-8$ & 5344 & $-1,084$ & 278 & 5395,5 &,- 974 & ,330 \\
\hline $7-8$ & 8407,5 &,- 086 & 931 & 8317,5 &,- 235 & ,815 \\
\hline
\end{tabular}

SPSS ile ANOVA sonrasında yapılan Post-Hoc testlerinde karşılaştırılan grup sayısı ne olursa olsun, toplamda yapılabilecek hata oranı anlamlılık seviyesi kadardır. Fakat parametrik olmayan analizlerde Post-Hoc analizinin araştırmacının kendisi tarafından tanımlanması gerektiğinden, yapılacak ikili karşılaştırma testi sayısı arttıkça, toplamda yapılan hata oranı \%5'i aşacaktır. Bu nedenle, Kruskal Wallis $\mathrm{H}$ testi sonrası yapılacak ikili karşılaştırma testlerinde toplam hatanın \%5'i aşmaması için Bonferroni Düzeltmesi yapılması tavsiye edilir (Akbulut, 2010; Akt. Bursal, 2017). Düzeltilmiş Anlamlılık Düzeyi= 0,05/(Yapılacak İkili Karşılaştırma Testi Sayısı) olduğuna göre dört alt grubun birbiri ile karşılaştırıldığı bir durumda yapılan Bonferroni Düzeltmesi sonrası ikili karşılaştırma testlerinde anlamlılık düzeyi 0,05/6=0,0083 olarak esas alınmıştır. Yansıtıcı düşünme becerisi ele alındığında Tablo 10 'da verilen $p=0,007$ değeri düzeltilmiş anlamlılık düzeyinden düşük $(p<0,0083)$ olduğu için 5 . - 8. sınıf gruplarının yansıtıcı düşünme becerileri arasında beşinci sınıfların ortalama sıra değeri 125,13'ün sekizinci sınıfların ortalama sıra değeri olan 100,96'dan büyük olması beşinci sınıf lehine istatistiksel olarak anlamlı farklılığın olduğunu gösterir. Öz yeterlik algısı incelendiğinde ise Tablo 10 'da verilen $p=0,006$ değeri düzeltilmiş anlamlılık düzeyinden düşük $(p<0,0083)$ olduğu için 5.-7. sınıf gruplarının öz yeterlik algıları arasında beşinci sınıfların ortalama sıra değeri 113,05'in yedinci sınıfların ortalama sıra değeri olan 89,98'den büyük olması yine beşinci sınıf lehine istatistiksel olarak anlamlı farklılığın olduğunu göstermektedir.

\section{Ortaokul öğrencilerinin karne notlarına göre problem çözmeye yönelik yansıtıcı düşünme becerileri ve öz yeterlik algıları}

Ortaokul öğrencilerinin yansıtıcı düşünme becerilerinin ve öz yeterlik algılarının karne notuna göre farklılık gösterip göstermediğini açığa çıkarmak için öncelikli olarak normal dağılım varsayımı hakkında bilgi veren Kolmogorov-Smirnov testi uygulanmıştır. Yansıtıcı düşünme becerisi ölçeğinde 1-2 notuna ait $p$ değeri $(p=, 350), 3$ notuna ait $p$ değeri ( $p=, 200)$ ve 4 notuna ait $p$ değeri $(p=, 200) 0,05$ değerinden büyük olmasına rağmen 5 notuna ait $p$ değerinin $(p=, 000) 0,05$ değerinden küçük olması normal dağılım varsayımını göstermemektedir. Öz yeterlik algısı ölçeğinde ise 1-2 notuna ait $p$ değeri $(p=, 928) 0,05$ değerinden büyük olmasına rağmen, 3 notuna ait $p$ değeri $(p=, 049), 4$ notuna ait $p$ değeri $(p=, 004)$ ve 5 notuna ait $p$ değerinin $(p=, 000) 0,05$ değerinden küçük olması normal dağılım varsayımını göstermemektedir. Dolayısıyla parametrik olmayan testlerden Kruskal Wallis testi kullanılmıştır. Karne notu 1 olan sadece 2 kişi olduğu için karne notu 1 ve 2 olan öğrenciler birleştirilerek yeni bir grup oluşturulmuş ve analizlere bu şekilde devam edilmiştir. Karne notlarına göre yansıtıcı düşünme becerisi ve öz yeterlik algısı puanlarına ait betimsel değerler Tablo 11'de sunulmuştur.

Tablo 11. Karne notuna göre yansıtıcı düşünme becerisi ve öz yeterlik algısı puanlarının betimsel değerleri

\begin{tabular}{|c|c|c|c|}
\hline Karne Notu & İstatistik & Yansıtıcı Düşünme Becerisi & Öz Yeterlik Algısı \\
\hline \multirow{5}{*}{$1-2$} & Ortalama & 47,2857 & 46,7143 \\
\hline & Medyan & 49 & 47 \\
\hline & Standart sapma & 8,99524 & 7,64946 \\
\hline & Çarpıklık &,- 087 & ,060 \\
\hline & Basıklık & $-1,111$ & 913 \\
\hline 3 & Ortalama & 49,1857 & 47,5714 \\
\hline
\end{tabular}

| Kastamonu Eğitim Dergisi, 2020, Vol. 28, No. 6| 


Medyan
Standart sapma
Çarpıklık
Basıklık
Ortalama
Medyan
Standart sapma
Çarpıklık
Basıklık
Ortalama
Medyan
Standart sapma
Çarpıklık
Basıklık

49,5
7,68075
,- 266
, 028
51,3333
52
7,04569
,- 569
, 252
53,6359
54
8,82275
,- 674
, 267

48,5

8,37798

$-, 395$

,614

48,0444

50

9,19350

$-, 728$

,326

52,6667

54

10,27241

$-, 964$

,766

Yapılan Kruskal Wallis testinde yansıtıcı düşünme becerisi için hesaplanan anlamlılık değeri $p=0,000<0,05$ olduğundan öğrencilerin yansıtıcı düşünme becerilerinin karne notuna göre anlamlı bir biçimde farklılık gösterdiği kararına varılabilir $\left[X^{2}(3\right.$, $n=421)=26,092 ; p=0,000$ ]. Öz yeterlik algısı için hesaplanan anlamlılık değeri $p=0,000<0,05$ olduğundan öğrencilerin öz yeterlik algılarının da karne notuna göre anlamlı bir biçimde farklılık gösterdiği ifade edilebilir $\left[X^{2}(3, n=421)=37,559 ; p=0,000\right]$. Alt gruplar arasındaki farklılıkların tespiti için parametrik olmayan testlerden iki bağımsız örneklemi karşılaştıran Mann Whitney $U$ testi kullanılmıştır. Dört grup karşılaştırıldığı için Bonferroni düzeltmesi sonrası ikili karşılaştırma testlerinde anlamlılık düzeyi $0,05 / 6=0,0083$ olarak temel alınmıştır. Tablo 12 'de Kruskal Wallis testi sonuçları verilmiştir.

Tablo 12. Kruskal Wallis $\mathrm{H}$ testi sonrası ikili karşılaştırmalar (Mann Whitney U testi istatistiği)

\begin{tabular}{|c|c|c|c|c|c|c|}
\hline \multirow{2}{*}{ Karne Notu } & \multicolumn{3}{|c|}{ Yansıtıcı Düşünme Becerisi } & \multicolumn{3}{|c|}{ Öz Yeterlik Algısı } \\
\hline & $U$ & $z$ & $p$ & $U$ & $z$ & $p$ \\
\hline$(1-2)-3$ & 650,5 &,- 797 & ,426 & 656 &,- 745 & ,456 \\
\hline$(1-2)-4$ & 1050,5 & $-1,908$ & ,056 & 1197,5 & $-1,143$ & ,253 \\
\hline$(1-2)-5$ & 1222,5 & $-3,034$ & ,002 & 1167,5 & $-3,236$ & ,001 \\
\hline $3-4$ & 3890 & $-2,075$ & 038 & 4395,5 &,- 819 & ,413 \\
\hline $3-5$ & 4555,5 & $-4,129$ & ,000 & 4292 & $-4,608$ & ,000 \\
\hline $4-5$ & 10600 & $-3,010$ & ,003 & 9096 & $-4,775$ & 000 \\
\hline
\end{tabular}

Tablo 13. Anlamlı fark bulunan grupların yansıtıcı düşünme becerisi ve öz yeterlik algısı puanlarına ait Mann Whitney $U$ testi sıraları

\begin{tabular}{lcccc}
\hline Anket & Sınıf & $n$ & Sıra Ortalaması & Sıralar Toplamı \\
\hline \multirow{2}{*}{ Yansıtıcı Düşünme Becerisi } & $1-2$ & 21 & 69,21 & 1453,50 \\
\hline \multirow{2}{*}{ Yansıtııı Düşünme Becerisi } & 5 & 195 & 112,73 & 21982,50 \\
\hline \multirow{2}{*}{ Yansıtıcı Düşünme Becerisi } & 3 & 70 & 100,58 & 7040,50 \\
& 5 & 195 & 144,64 & 28204,50 \\
\multirow{2}{*}{ Öz Yeterlik Algısı } & 4 & 135 & 146,52 & 19780 \\
& 5 & 195 & 178,64 & 34835 \\
\multirow{2}{*}{ Öz Yeterlik Algısı } & $1-2$ & 21 & 66,60 & 1398 \\
& 5 & 195 & 113,01 & 22037 \\
\hline \multirow{2}{*}{ Öz Yeterlik Algısı } & 3 & 70 & 96,81 & 6777 \\
& 5 & 195 & 145,99 & 28468 \\
\hline
\end{tabular}

Yansıtıcı düşünme becerisi için Tablo 12 'de verilen $p$ değerleri 0,002, 0,000 ve 0,003 düzeltilmiş anlamlılık düzeyinden düşük ( $p<0,0083$ ) olmaktadır. (1-2) -5, 3-5 ve 4-5 karne notu gruplarının yansıtıcı düşünme becerileri arasında Tablo 13 'te gösterildiği gibi 5 notunu alanların lehine istatistiksel olarak anlamlı farklılık vardır. Öz yeterlik algısı için Tablo 12 'de verilen $p$ değerleri 0,001 ve 0,000 düzeltilmiş anlamlılık düzeyinden düşük $(p<0,0083)$ hesaplanmıştır. (1-2)-5, 3-5 ve 4-5 karne notu gruplarının yansıtıcı düşünme becerilerine ek olarak öz yeterlik algıları arasında da Tablo 13'te gösterildiği gibi 5 notunu alanların lehine istatistiksel olarak anlamlı farklılık vardır.

\section{TARTIŞMA}

Araştırma bulgularına göre ortaokul öğrencilerinin yansıtıcı düşünme becerisi ve öz yeterlik algı düzeyleri incelendiğinde, ortaokul öğrencilerinin problem çözmeye yönelik yansıtıcı düşünme becerisi ve matematik öz yeterlik algı düzeylerinin aldıkları puan bazında yüksek olduğu görülmüştür. Ortaöğretim öğrencilerinin problem çözmeye yönelik yansıtıcı düşünme becerilerini bazı değişkenler açısından inceleyen Erdoğan'ın (2019) çalışmasında öğrencilerin yansıtıcı düşünme becerilerinin genel seviyesi düşük 
düzeyde bulunmuştur. Alınan sonuç yapılan çalışmalarla karşılaştırıldığında bu değerlerin bilim sanat merkezi ve üstün yetenekli çocuklar ile yapılan çalışmalardan elde edilen puanlardan düşük olduğu görülmektedir (Güneş, 2015; Kaplan, Doruk ve Öztürk, 2014; Saygılı ve Atahan, 2014). Bunun nedeni bu öğrencilerin sınavla seçilerek okullara alınmasına bağlı olduğunu düşündürmektedir. Ayrıca ilköğretim okullarında yapılan araştırmalarda daha yüksek ortalamaların elde edildiği gözlemlenmiştir (Bilgiç, 2017). Bu puanların yüksek olması ilkokul ve ortaokul öğretim programlarında yansıtıcı düşünmenin daha aktif olarak kullanılabildiğini göstermektedir.

İpek'in (2019) çalışmasında ortaokul öğrencilerinin matematik öz yeterlik algıları orta seviyede bulunmuştur. Fakat bu çalışmada ortaokul öğrencilerinin öz-yeterlik algıları orta seviyenin üzerinde bulunmuştur. Örneklem farklılıklarından kaynaklı olarak öz-yeterlik seviyeleri orta veya ortanın üzerinde bulunabilmektedir. Kısacası ortaokul öğrencilerinde öz yeterlik genellikle ortalamanın altında olmamaktadır. Öğrenciler merkezi sınavlara daha tam olarak alışkın olmadıklarından öz-yeterlik seviyelerini de korumaktadırlar. Akay ve Boz'un (2011) çalışmasında ise sınıf öğretmeni adaylarının matematiğe yönelik tutumları, matematiğe karşı öz-yeterlik algıları ve öğretmen öz-yeterlik inançları arasındaki ilişkiler incelenmiştir. Örneklemdeki öğrencilerin matematik ve öğretmenlik mesleğine ilişkin tutumlarının, matematik öz-yeterlik algılarının ve akademik başarılarının yeterli düzeyde yüksek olduğu ortaya çıkmıştır. Bu çalışmada da ortaokul öğrencilerinin öz-yeterlikleri ortalamanın üzerinde çıkmıştır. Bandura'ya (1997) göre bir kişinin kendi yetenek ve becerilerine olan güveni, inancı, güçlüklerin üstesinden gelmek için bir ön şarttır. Öz yeterlik algısı yüksek olan bireyler zor ve başa çıkması gereken öğrenme görevlerinde daha kararlı, daha fazla gayretli, daha ısrarcı ve daha pozitif olmaktadırlar (Zimmerman, 2000). Dolayısıyla öğrencilerin matematik öz yeterlik algısı, bir konuyu başarılı bir şekilde öğrenme kapasiteleri ve inançları hakkında bilgi vermektedir. Öğrenenlerde, yaş seviyesi ne olursa olsun yani ister ortaokul öğrencisi ister ortaokul öğrencisinin öğretmeni öz yeterlik seviyesi duyuşsal bileşenlerle birleşmektedir. Öğrenenler aslında öz-yeterlik seviyelerini yüksek tutarak öğrenmeye açık olduklarını da göstermektedirler. Diğer duyuşsal bileşenlerle birlikte baktığımızda öğrenen öğrenmeye istekli ve belli bir seviyede yapabileceği öğrenebileceği inancı ile öğrenime devam edebilmektedir.

Elde edilen bulgular cinsiyet bazında değerlendirildiğinde, ortaokul öğrencilerinin cinsiyet açısından problem çözmeye yönelik yansıtıcı düşünme becerileri arasında ve matematik öz yeterlik algıları arasında istatistiksel olarak anlamlı farklılık olmadı̆̆ı görülmüştür. Benzer olarak, Saygılı ve Atahan (2014) tarafından yapılan araştırmada üstün zekâlı çocukların yansıtıcı düşünme becerilerinin cinsiyete göre değişmediği ifade edilmiştir. Benzer bir biçimde Durdukoca ve Demir'in (2012) çalışmasında yansıtıcı düşünme eğilimi ile cinsiyet arasında istatistiksel olarak anlamlı ilişkinin olmadığı belirtilmiştir. Buna karşın, alan yazında araştırma bulgularının aleyhinde sonuçlar bulan araştırmalara da rastlanmaktadır. Tat'ın (2015) araştırmasında, kız öğrencilerin problem çözmeye yönelik yansıtıcı düşünme becerilerinin erkek öğrencilere göre daha yüksek olduğu sonucuna ulaşılmıştır. Benzer araştırmalar yapan Aslan (2009) ve Ceyhan (2014) tarafından ise yansıtıcı düşünme becerisi düzeyinin cinsiyete göre kadınlar lehine farklılaştığı tespit edilmiştir. Cinsiyet açısından bir farklılık olmaması öğrencilerin yansıtıcı öğrenme ve öz-yeterlilik seviyelerini yukarıya taşıyacak etkinlikler sınıf içi öğrenme ortamları oluşturulurken dikkat edilmemesi gereken bir değişken olduğunu bize göstermiştir. Alanda cinsiyetler arası farkılıkları bulan çalışmaların sonuçlarını da görmezden gelmeyerek bu değişkenin farklı örneklemlerde etkili olacağı da unutulmamalıdır.

Terzi ve Mirasyedioğlu'nun (2009) yaptıkları çalışmada erkek öğrencilerin matematik öz yeterlik algıları, kız öğrencilerin matematik öz yeterlik algılarından yüksek bulunmuştur. Alan yazında Pajares ve Miller (1994), Junge ve Beverly (1995) tarafından erkek öğrencilerin kız öğrencilere oranla matematik öz-yeterlik algılarının daha yüksek olduğu belirtmişlerdir. Bazı çalışmalarda da araştırmamız lehine matematik öz yeterlik algısının cinsiyete göre bir farklılık göstermediği ifade edilmiştir (Lent, Brown ve Larkin, 1984; Hackett, 1985; Cooper ve Robinson Debra, 1991). Öz-yeterlilik kızlar ve erkeklerde duyuşsal olarak ortaokul öğrencileri arasında farklılık yaratmadığından öğrenme ortamlarında ilk sıralarda yer almasına gerek kalmamış olabilir. Öğrencilerimizin özyeterliliğin etkilenmesini veya artırılmasını planlarken ilk sıralarda cinsiyete dikkat etmemiz o kadar önemli olmayabilir.

Yapılan analizler ışığında elde edilen bir diğer bulgu değişkenler arasında ilişki konusudur. Ortaokul öğrencilerinin problem çözmeye yönelik yansıtıcı düşünme becerisi ile matematik öz yeterlik algısı arasında orta düzeyde, pozitif ve istatistiksel olarak anlamlı bir ilişki olduğu görülmüştür. Alan yazında iki değişken arasındaki ilişkiyi ölçen herhangi çalışmaya rastlanmamıştır. Fakat duyuşsal değişkenlerde öz düzenleme ve yansıtıcı düşünme arasında da orta düzeyde ilişki bulan çalışmalar bulunmaktadır. Duyuşsal beceriler ile yansıtıcı düşünme arasında pozitif ilişki olması ikisinden birisine yoğunlaştığımızda diğerinin de pozitif yönde değişmeye başlayacağını bize gösterecektir.

Ortaokul öğrencilerinin problem çözmeye yönelik yansıtıcı düşünme becerisi ve öz yeterlik algısı sınıf düzeyine göre değerlendirildiğinde, beşinci sınıflar ile sekizinci sınıfların yansıtıcı düşünme becerileri arasında beşinci sınıf lehine istatistiksel olarak anlamlı farklılık vardır. Öz yeterlik algısı için beşinci sınıflar ile yedinci sınıfların öz yeterlik algıları arasında da beşinci sınıf lehine istatistiksel olarak anlamlı farklılık vardır. Bu bağlamda sınıf seviyesi arttıkça yansıtıcı düşünme becerisi ve öz yeterlik algısının düştüğünü söyleyebiliriz. Ortaöğretim öğrencilerinin problem çözmeye yönelik yansıtıcı düşünme becerilerini bazı değişkenler açısından inceleyen Erdoğan'ın (2019) araştırmasında sınıf düzeyi yükseldikçe öğrencilerin problem çözmeye yönelik yansıtıcı düşünme becerisi düzeylerinin arttığı gözlemlenmiştir. Dolayısıyla, sınıf düzeyi yükseldikçe öğrencilerin problem çözmeye yönelik yansıtıcı düşünme becerilerinin de arttığı düşünülebilir. Fakat 12. sınıfa gelen öğrencilerin problem çözmeye yönelik yansıtıcı düşünme seviyelerinin düşüşe geçtiği belirtilmektedir. Bu durumun sebebinin öğrencilerin 12. sınıfta yaşadığı sınav stresinin problem çözmeye yönelik yansıtıcı düşünme becerisi düzeylerini etkilemiş olabileceği düşünülmektedir.

Öte yandan İpek'in (2019) araştırmasında ortaokul öğrencilerinin matematiksel öz yeterliklerinin sınıf seviyelerine göre anlamlı olarak farklılaştığı görülmektedir. Genel olarak alt sınıflardaki öğrenciler üst sınıflardaki öğrencilere göre istatistiksel olarak anlamlı

| Kastamonu Eğitim Dergisi, 2020, Vol. 28, No. 6| 
ölçüde daha yüksek puanlar almışlardır. Bu sonuç, araştırmadan elde edilen bulgulara paralellik göstermektedir. Öğrencilerin sınıf seviyesindeki artış ile merkezi sınavlara hazırlanma kaygısı ya da nitelikli liselerden hangisine gidebileceğinin kaygısı öğrencilerin öz-yeterlik seviyelerinde düşüşe yol açabilir. Meslek seçiminde hangi alanda okuyacağının kaygısı da öğrenciler üzerinde öz yeterlik seviyesini negatif etkileyebilmektedir. Sınıf seviyesiyle birlikte matematikte konuların soyutlaşmaya ve artık matematik dilinin iyice oturmaya başlaması da öğrencilerin temel matematik konuları tam olarak oluşmadıysa öz yeterliliklerinin düşmesine neden olabilmektedir.

Bu araştırmada ortaokul öğrencilerinin problem çözmeye yönelik yansıtıcı düşünme becerisi ve matematik öz yeterlik algıları konusunda bir diğer anlamlı bulgu ise karne notlarına göre ortaya çıkan farklılıklardır. Analizlere göre yansıtıcı düşünme becerisi için (1-2)-5, 3-5 ve 4-5 karne notu gruplarının yansıtıcı düşünme becerileri arasında beş notunu alanların lehine istatistiksel olarak anlamlı farklııık vardır. Öz yeterlik algısı için (1-2)-5, 3-5 ve 4-5 karne notu gruplarının yansıtıcı düşünme becerilerine ek olarak öz yeterlik algıları arasında da beş notunu alanların lehine istatistiksel olarak anlamlı farklılık vardır. Dolayısıyla genel olarak öz yeterlik algısına ait ölçekten başarılı öğrencilerin daha yüksek puanlar aldıkları görülmüştür. Alan yazında bu bulguyu destekleyen çok sayıda araştırmanın varlığından bahsedilebilir. Öz yeterlik hemen hemen bütün öğrenme alanlarında akademik başarılara güçlü olarak etki etmektedir (Mills ve ark., 2007; Özkeleş Çağlayan, 2010; Duran, 2011; Taşdemir, 2012). Margolis ve McCabe'e (2006) göre düşük öz yeterlik inancı ders başarısını engellemekte, uzun süreçte psikolojik durumu kötü yönde etkileyerek başarısızlık algısı geliştirmekte ve öğrenilmiş çaresizliği açığa çıkarmaktadır.

Öğrencilerin sorun çözme becerisini geliştiren, problemler üzerinde tüm boyutları ile ve derinlemesine düşündüren, tüm bunların sonucunda aldığı eğitimi gerçek hayata aktarabilen problem çözmeye yönelik yansıtıcı düşünme becerisi eğitimde kazandırılması gereken en önemli becerilerinden biridir. Problem çözmeye yönelik yansıtıcı düşünme becerisinin yapacağı katkılar dikkate alındığında bu konu üzerinde yapılacak araştırmaların çok önemli bir konuma sahip olduğu açığa çıkmaktadır. Öte yandan matematik öğretiminde üzerinde durulması gereken bir diğer önemli değişkenin öz yeterlik algısı olduğu söylenebilir. Öz yeterlik inancının yüksek olması, bireylerin kendilerine yüksek hedefler koymasını, verdikleri kararlarda tutarlı olmalarını, bilişsel süreçlerinin ve motivasyonlarının daha da yüksek olmasını sağlamaktadır (Locke ve Latham, 1990). Bu değişkenlerin önemi göz önüne alındığında, eğitim öğretim programları okul öncesinden başlanarak düzenlenebilir ve düşünme becerilerinin nasıl kazandırılabileceği konusunda araştırmalar yapılabilir. Ayrıca ilköğretim öğrencileri ile yapılan çalışmalarda problem çözmeye yönelik yansıtıcı düşünme becerilerinin yüksek olması fakat sınıf düzeyi arttıkça bu becerilerin düşmesinin nedenleri araştırılabilir.

\section{Etik Kurul Onay Bilgileri}

Bu araştırma, Erciyes Üniversitesi Sosyal ve Beşerî Bilimler Etik kurulunun 25/02/2020 tarihli ve 24 numaralı başvuruya istinaden alınan izinle yürütülmüştür.

\section{KAYNAKÇA}

Akay, H. ve Boz, N. (2011). Sınıf öğretmeni adaylarının matematiğe yönelik tutumları, matematiğe karşı öz-yeterlik algıları ve öğretmen öz-yeterlik inançları arasındaki ilişkilerin incelenmesi. Türk Eğitim Bilimleri Dergisi, 9(2), 281-312.

Akbulut, Y. (2010). Sosyal bilimlerde SPSS uygulamaları. İstanbul: İdeal Kültür Yayıncılık.

Aslan, G. (2009). Sınıf öğretmenlerinin yansıtıı düşünme eğilimleri ile sürekli kaygı düzeyleri arasındaki ilişkinin incelenmesi (Yayımlanmamış yüksek lisans tezi). Yeditepe Üniversitesi, İstanbul.

Bandura, A. (1986). Social foundation of thought and action: A Social cognitive theory. Englewood Cliffs. NJ: Prentice Hall.

Bandura, A. (1997). Self - efficacy: The exercise of control. Freeman and Company: USA.

Baş, G. ve Kıvılcım, Z. S. (2013). Lise öğrencilerinin problem çözmeye yönelik yansıtıcı düşünme becerileri ile matematik ve geometri derslerindeki akademik başarıları arasındaki ilişki. Ahi Evran Üniversitesi Kırşehir Eğitim Fakültesi Dergisi (KEFAD), 14(3), 1-17.

Bilgiç, C. (2017). Ilköğretim öğrencilerin problem çözmeye yönelik yansıtıcı düşünme becerileri ve sosyal bilgiler dersi akademik başarıları (Yayımlanmamış yüksek lisans tezi). Uşak Üniversitesi, Uşak.

Binghan, A. (2004). Çocuklarda problem çözme yeteneklerinin geliştirilmesi. İstanbul: Milli Eğitim Yayınevi.

Boyd, E. M. ve Fales, A. W. (1983) Reflective learning: Key to learning from experience. Journal of Humanistic Psychology, 23(2), 99-117.

Bursal, M. (2017). SPSS ile temel veri analizleri. Ankara: Anı Yayıncılık.

Ceyhan, G. (2014). Üniversite öğrencilerinin yansıtıcı düşünme düzeyleri ve araştırmaya yönelik kaygılarının çeşitli değişkenler açısından cart analizi ile incelenmesi (Yayımlanmamış yüksek lisans tezi). Yüzüncü Yıl Üniversitesi, Van.

Christensen, L. B., Johnson, B. R. ve Turner, L. A. (2015). Araştırma yöntemleri desen ve analiz (Çev. Ed. A. Aypay). Ankara: Anı Yayıncılık.

Cooper, S. E. ve Robinson Debra, A. G. (1991). The relationship of mathematics self-efficacy beliefs to mathematics anxiety and performance. Measurement and Evaluation in Counseling and Development, 24(1), 4-11.

Çağırgan-Gülten, D. (2013). Illköğretim matematik öğretmen adaylarının matematik okuryazarlık öz-yeterlilik inançlarının çeşitli değişkenler açısından incelenmesi. International Online Journal of Educational Sciences, 5(2), 393-408.

Dewey, J. (1933). How we think. A restatement of the relation of reflective thinking to the educative process. Boston: D. C. Heath.

Doruk, M., Öztürk, M. ve Kaplan, A. (2016). Ortaokul öğrencilerinin matematiğe yönelik öz-yeterlik algılarının belirlenmesi: kaygı ve tutum faktörleri. Adıyaman Üniversitesi Eğitim Bilimleri Dergisi, 6(2), 283-302. 
Duran, M. (2011). Ilköğretim 7. sınıf öğrencilerinin görsel matematik okuryazarlığı özyeterlik algıları ile görsel matematik başarıları arasındaki ilişki (Yayımlanmamış yüksek lisans tezi). Erzincan Üniversitesi, Erzincan.

Durdukoca, Ş. F. ve Demir, M. (2012). illköğretim öğretmenlerin bazı değişkenlere göre yansıtıcı düşünme düzeyleri ve düşüncelerindeki öğretmen niteliklerinin yansıtıcı öğretmen niteliklerine uygunluğu. Mustafa Kemal Üniversitesi Sosyal Bilimler Enstitüsü Dergisi, 9(20), 357-374.

Erdoğan, A. (2019). Ortaöğretim öğrencilerinin problem çözmeye yönelik yansıtıcı düşünme becerilerinin bazı değiş̧enler açısından incelenmesi (Yayımlanmamış yüksek lisans tezi). Necmettin Erbakan Üniversitesi, Konya.

Ersözlü, Z. N. ve Kazu, H. (2011). Illköğretim beşinci sınıf sosyal bilgiler dersinde uygulanan yansıtıcı düşünmeyi geliştirme etkinliklerinin akademik başarıya etkisi. Uludağ Eğitim Fakültesi Dergisi, 24(1), 141-159.

Güneş, K. (2015). Bilim sanat merkezi öğrencilerinin problem çözmeye yönelik yansıtıcı düşünme becerileri, matematik dersine yönelik tutumları ve matematik başarılarının incelenmesi (Yayımlanmamış yüksek lisans tezi). Çukurova Üniversitesi, Adana.

Güney, K. (2008). Mikro-yansıtıcı öğretim yönteminin öğretmen adaylarının sunu performansı ve yansıtıcı düşünmesine etkisi (Yayımlanmamış doktora tezi). Fırat Üniversitesi, Elâzı̆̆.

Hackett, G. (1985). Role of mathematics self efficacy in the choice of mathematics-related majors of college women and men: A path analysis. Journal of Counseling Psychology, 32, 47-56.

Howitt, D. ve Cramer, D. (2011). Introduction to SPSS statistics in psychology: For version 19 and earlier (Fifth edition). London: Pearson Education Limited.

İpek, H. (2019). Ortaokul öğrencilerinin matematik kaygılarının matematik öz yeterlik inançlarının ve matematik dersine yönelik öz düzenleme becerilerinin incelenmesi (Yayımlanmamış yüksek lisans tezi). Marmara Üniversitesi, İstanbul.

Junge, M. E. ve Beverly, J. D. (1995). Mathematical self-efficacy gender differences in gifted/talented adolescents. Gifted Child Quarterly, 39(1), $22-26$.

Kandemir, M. (2015). İlköğretim matematik ve sınıf öğretmenliği adaylarının yansıtıcı düşünme eğilim düzeylerinin bazı değişkenlere göre incelenmesi. Education Sciences, 10(4), 253-275.

Kaplan, A., Doruk, M. ve Öztürk, M. (2017). Üstün yetenekli öğrencilerin problem çözmeye yönelik yansıtıcı düşünme becerilerinin incelenmesi: Gümüşhane örneği. Bayburt Eğitim Fakültesi Dergisi, 12(23), 415-435.

Kaptan, F. ve Korkmaz, H. (2001). Fen eğitiminde probleme dayalı öğrenme yaklaşımı. Hacettepe Üniversitesi Eğitim Fakültesi Dergisi, 20(20), 185-192.

Karasar, N. (2012). Bilimsel araştırma yöntemi. Ankara: Nobel Yayıncılık.

Karademir, Ç. A. ve Görgün, S. (2019). Ortaokul öğrencilerinin problem çözmeye yönelik yansıtıcı düşünme becerileri ile öz-düzenleme becerilerinin incelenmesi. Avrasya Uluslararası Araştırmalar Dergisi, 7(16), 292-313.

Kızılkaya, G. ve Aşkar, P. (2009). Problem çözmeye yönelik yansıtıcı düşünme becerisi ölçeğinin geliştirilmesi. Eğitim ve Bilim, 34(154), 82-92.

Kurtuluş, A. ve Eryılmaz, A. (2017). Matematik dersinde akış ile problem çözmeye yönelik yansıtıcı düşünme becerisi arasındaki ilişki. Kuramsal Eğitimbilim Dergisi, 10(3), 349-365.

Köseoğlu, E., Demirci, F. Demir, B. ve Özyürek, C. (2017). 7. sınıf öğrencilerinin problem çözmeye yönelik yansıtıcı düşünme becerilerinin incelenmesi: Ordu ili örneği. International e-Journal of Educational Studies (IEJES), 1(1), 60-68.

Lent, R. W., Brown, S. W. ve Larkin, K. C. (1984). Relation of self efficacy expectations to academic achievement and persistence. Journal of Counseling Psychology, 31, 356-362.

Lind, D. A., Marchal, W. G. ve Wathen, S. A. (2006). Basic statistics for business and economics (Fifth edition). United States: McGraw-Hill Companies.

Locke, E. A. ve Latham, G. P. (1990). A Theory of goal setting and task performance. Englewood cliffs, NJ: Prentice Hall.

Margolis, H. ve McCabe, P. P. (2006). Improving self-efficacy and motivation: What to do, what to say. Intervention in School and Clinic, 41(4), 218-227.

McKillup, S. (2012). Statistics explained: An introductory guide for life scientists (Second edition). United States: Cambridge University Press.

Mills, N., Pajares, F. ve Herron, C. (2007). Self-efficacy of college intermediate French students: Relation to achievement and motivation. Language Learning, 57(3), 417-442.

Özkeleş Çağlayan, S. (2010). Lise I. Sınıf öğrencilerinin geometri dersine yönelik özyeterlik algııı ve tutumunun geometri dersi akademik başarısını yordama gücü (Yayınlanmamış yüksek lisans tezi). Yıldız Teknik Üniversitesi, İstanbul.

Özbek, G. ve Köse, E. (2019) Öğretmen adaylarının yansıtıcı düşünme becerileri ve bu becerilerin gelişimini destekleyen faktörler. Kastamonu Eğitim Dergisi, 27(2), 527-554. DOI: 10.24106/kefdergi.2577

Özgen, K. ve Bayram, B. (2020) Ortaokul öğrencilerinin problem kurmaya yönelik beceri ve öz yeterlik inançlarının incelenmesi. YYÜ Eğitim Fakültesi Dergisi (YYU Journal of Education Faculty), 17(1), 455-485.

Pajares, F. (1996). Self-efficacy beliefs in academic settings. Review of Educational Research, 66(4), 543-578.

Pajares, F. ve Miller, D. M. (1994). Role of self-efficacy and self-concept beliefs in mathematics problem solving: A path analysis. Journal of Educational Psychology, 86(2), 193-203.

Saban, A. (2005). Çoklu zekâ teorisi ve eğitim. Ankara: Nobel Yayıncılık.

Saygılı, G. ve Atahan, R. (2014). Üstün zekâlı çocukların problem çözmeye yönelik yansıtıcı düşünme becerilerinin çeşitli değişkenler bakımından incelenmesi. Süleyman Demirel Üniversitesi Fen Edebiyat Fakültesi Sosyal Bilimler Dergisi, (31), 181-192.

Schön, D. (1987). Educating the reflective practitioner: Toward a new design for teaching and learning in the professions. San Francisco: Jossey Bass.

|Kastamonu Eğitim Dergisi, 2020, Vol. 28, No. 6| 
Schunk, D. H. (1989). Self-efficacy and cognitive achievement: Implications for students with learning problems. Journal of Learning Disabilities, 22(1), 14-22.

Senemoğlu, N. (2005). Gelişim, öğrenme ve öğretim kuramdan uygulamaya (12. Basım). Ankara: Gazi Kitabevi.

Tabachnick, B. G. ve Fidell, L. S. (2013). Using multivariate statistics (Sixth edition). United States: Pearson Education.

Taşdemir, C. (2012). Lise son sınıf öğrencilerinin matematik öz-yeterlik düzeylerinin bazı değişkenler açısından incelenmesi (Bitlis ili örneği). Karadeniz Fen Bilimleri Dergisi, 2(6), 39-50.

Tat, O. (2015). Ortaokul öğrencilerinin problem çözmeye yönelik yansıtıcı düşünme becerilerini etkileyen faktörlerin hiyerarşik doğrusal modeller ile incelenmesi (Yayımlanmamış yüksek lisans tezi). Yüzüncü Yıl Üniversitesi, Van.

Terzi, M. ve Mirasyedioğlu, ş. (2009). İlköğretim matematik öğretmen adaylarının matematiğe yönelik özyeterlik algılarının bazı değişkenler açısından incelenmesi. Türk Bilim Araştırma Vakfı Bilim Dergisi, 2(2), 257-265.

Umay, A. (2001). İlköğretim matematik öğretmenliği programının matematiğe karşı öz yeterlik algısına etkisi. Journal of Qafqaz University, 8(1), 1-8.

Ülker, M. (2019). Öz düzenleme ve yansıtıcı düşünmenin matematik başarısına etkisinin incelenmesi (Yayımlanmamış yüksek lisans tezi). Balıkesir Üniversitesi, Balıkesir.

Ünver, G. (2003). Yansıtıcı düşünme. Ankara: Pegem Yayıncılık.

Yıldız, M. (2018). İlkokul 4. sınıf fen bilimleri dersinde yansıtıcı öğretim ile desteklenmiş basamaklı öğretimin akademik başarıya ve tutuma etkisi (Yayımlanmamış yüksek lisans tezi). Bartın Üniversitesi, Bartın.

Wilcox, R. R. (2012). Modern statistics for the social and behavioral sciences: A practical introduction. United States: Chapman \& Hall/CRC Press.

Zimmerman, B. J. (2000). Self-efficacy: An essential motive to learn. Contemporary Educational Psychology, 25(1), $82-91$. 